\title{
A framework for turnaround practitioners to assess reasonable prospect for ventures operating in the zone of insolvency
}

\author{
M. Pretorius * \\ Department of Business Management, University Pretoria, Private bag X20, Hatfield, 0028, South Africa \\ *To whom all correspondence should be addressed \\ marius.pretorius@up.ac.za or mariusstrategist@gmail.com
}

\begin{abstract}
Turnaround practitioners (TPs) and business rescue practitioners (BRPs) are tasked with making the critical decision of whether a distressed business has reasonable prospect (RP) for reorganisation. Creditors often require the same determination because only businesses assessed to have a reasonable prospect can enter the rescue or reorganisation process. These determinations are difficult because they are made within a 'zone of insolvency' (ZoI). Going concerns operate on a solvent basis but may slide into the ZoI where conditions are ambiguous, unclear and uncertain. At the same, time, the specific conditions and contexts of distressed businesses vary widely despite some generic similarities that may exist. Therefore, the decision about reasonable prospect depends largely on how TP and BRPs perceive and make sense of the ambiguous conditions within the zone of insolvency. Finally, creditors and courts rarely agree with such RP determinations, but no generic tool exists to satisfy all stakeholders. Hence, the decision of whether (or not) a distressed business has a reasonable prospect to embark upon a reorganisation intervention involves both rational and subjective assessment to make sense of the conditions present in the ZoI. An affordance framework with guiding scores is proposed to determine reasonable prospect.
\end{abstract}

\section{Introduction}

Pretorius (2014) suggests 'navigation' as the ultimate assignment of the Business Rescue Practitioner (BRP) stating that it requires 'plotting and ascertaining the current troubled situation (thus starting within the zone of insolvency (ZoI)), determining the best envisioned endpoint and then directing the reorganisation course to pursue through formulating strategies to affect a crossover. While there are three distinct elements (current distress position, best future position and crossover), the overlap is with varying levels of complexity associated with the specific case. Sense-making of the current distress levels in the ZoI forms the basis of this process to inform RP determination. It is a fact that not all companies should be allowed to pursue reorganisation (Eow, 2006:300). Only those with a reasonable prospect should be given the opportunity to pursue it (reorganisation) as few can prosper (Kahl, 2002:135) when they emerge from the process. Reasonable Prospect (RP) is, therefore, a commencement requirement for entering the process of informal turnaround and formal rescue. Sense-making of the current distress levels within the ZoI is the major determinant of reasonable prospect. How these cases are judged depends strongly on 'who makes the judgement' which leads to significant interpretation differences and conflict amongst debtors, creditors, practitioners, advisors, courts and regulators alike.

In this paper, I identify both the subjective and rational measures/factors that BRPs and turnaround managers could use to support decision making. This is all about whether to commence with a turnaround of a distressed business. The identification of these measures/factors is important because as Baird and Lorence (2012:12) observe within the turnaround industry, there is currently no broadly accepted tools, measures or processes to predict the success of turnaround practitioners. This research does not dispute the differences in perceptions of the decision makers; rather it embraces these differences as beneficial while searching for a framework that could encapsulate the subjectivity of the different perceptions to benefit all involved. Further, some turnaround managers believe their knowledge about these judgements equal their intellectual property, and therefore they do not share them openly. An important question remains namely: What are the critical objective and subjective measures/predictors/factors that can be used by BRPs to make decisions about RP for turnaround when operating within the ZoI?

In the next section, I first sketch the situation BRPs face on appointment. Second, I explore three key issues namely the ZoI (the event/situation), affordance theory as a perceptual frame for a reasonable prospect (RP) as commencement standard. Third, I then expand on related frameworks and elements to improve understanding of the complexity of the turnaround situations that may assist in determining the position of the firm in the ZoI. Finally, I propose a conceptual framework that makes two major contributions to the turnaround literature. The proposed framework describes the interactions between objective and subjective requirements within a reasonable prospect assessment for business reorganisation. The resulting framework does not claim to "lay down the correct method or approach in all cases" (Klopper \& Bradstreet, 2014:563) but one that could be used to direct the "factual" establishment of RP for use by TPs, BRPs, creditors, courts and other affected parties alike. 
Turnaround professionals and BRPs are required to make reasonable prospect assessments (decision making) every time they accept a turnaround and after that almost daily" (McCann, 2009) when they come face to face with the ZoI which remains elusive. Operating in the ZoI suggests ambiguous, unclear and uncertain conditions and timing for a distressed business on entry.

Going concerns operate on a solvent basis but may slide unexpectedly into the twilight zone and enter the ZoI. Operating in the ZoI suggests little real clarity exists on the exact characteristics and measurement thereof. While many contributing factors to the complexity of operating in the ZoI have been individually investigated in the various bodies of knowledge, there is a need for a comprehensive guideline or evaluation framework to explore the intricacies of the firm floating in the ZoI and facing decisions that may benefit all stakeholders. Tung (2006) quotes Smith (1976), who states that the ZoI remains an incoherent concept and that many firms are often operating in the ZoI because managers can always find a sizeable enough gamble that puts all the firm's equity at risk.

\section{Background to rescue and rescue practitioners}

As this paper contributes to enhanced understanding and attempts to expand practical theory of pre-insolvency activities, especially the event interpretation and commencement standard for a reasonable prospect (RP) during the ZoI, this section briefly summarises the context of business turnaround and specifically rescue for the reader and explicates the complexity associated with the ZoI.

\section{Specific background to business rescue in South Africa}

In May 2011, Chapter 6 of the Companies Act 71 of 2008 as amended (in this paper: the Act) came into effect. This allowed for a pre-insolvency procedure vaguely comparable to Chapter 11 in the United States (US) and administration in the United Kingdom (UK). Despite significant differences between the turnaround regimes of the US, Canada, UK and Australia and that of South Africa, Pretorius and RosslynSmith (2014) suggest several similarities to the acts governing such procedures. The legislation in different countries is also impacting on the evolution of turnaround processes as professionals move internationally (Bradstreet, 2010: Bryan, Cork \& Moffat, 2011:4) and apply principles generically.

Currently, BRPs are required to be independent on appointment suggesting very little option for involvement in the pre-assessment of a distressed venture. On appointment and within a very short time, BRPs are required to make sense of the current situation at filing, evaluate if RP for reorganisation (alternatively for pursuing a better return than in immediate liquidation (BRiL)) exists and then conceptualise the best new position and strategy to pursue. To enter business rescue, the threshold to enter is immediate or projected financial distress (s 128(1)(f)) and reasonable prospect to restore insolvency. A turnaround/rescue intervention mostly happens some period after entering the ZoI. Section 131 complicates the situational conditions providing for court applications by 'affected persons' to place a debtor company under supervision also stating the requirement of an RP determination. Often this is even more difficult due to information asymmetry. This paper, specifically, aims to develop a framework for such assessment of RP associated with the reorganisation of a firm that operates in the ZoI. Potentially such a framework could also serve as the commencement requirement by the courts when evaluating RP.

Much confusion, however, exists when comparing several court judgments of RP disputes (Joubert, 2013, BR Portal, 2013). In most of these cases, applications for business rescue were rejected in favour of liquidation with the absence of "factual" support for RP being the underlying reason. It confirms the importance of the research to design a framework for practical use, even if it may be at a rudimentary level for practical application when firms operate in the ZoI.

\section{Reasonable prospect as the main commencement standard}

The navigation metaphor (Pretorius, 2014) in BR assumes that BRPs must determine the existence of reasonable prospect and thus starts within the current situation of distress, which is subject to the uncertainties of the ZoI. Generally, the financial distress as event was brought on by either operational or strategic causes (Pretorius, 2008) but the extent (severity) of the distress remains unclear - therefore the concept referred to as the ZoI. Crucial for the BRP is to consider the position within the ZoI by identifying causality and its specific business consequences for a 'normal' business. BRPs are further required to continuously evaluate $\mathrm{RP}$, and if, at any time it is judged as absent (S141(2)(a)), they must file for liquidation.

Ill-defined as a concept, mostly applied from a legal perspective and a procedural commencement standard, reasonable prospect does not contribute towards 'demystifying' the ZoI, nor does it assist in understanding the processes required to support a decision on future action possibilities. Reasonable prospect speaks to the future attractiveness (Schmitt et al., 2015) in the relevant environment.

Clear requirements exist for 'burden of proof' for RP by the filing directors $(\mathrm{S} 129(1)(\mathrm{b}))$, opposing creditors (S130(1)(a)(i)) as well as the BRP (S135(b)(ii)) and the court (S131(4(a)(iii)). The BRP is required to judge RP continuously and if at any stage it appears that there is no reasonable prospect any more, filing for liquidation is prescribed $(\mathrm{S} 141(2)(\mathrm{a}))$.

However, and more important is the 'standard of proof' for $\mathrm{RP}$ which is not clear from the Act. Several cases are reported while Joubert (2013) explored the legal conversation of what 
constitutes reasonable prospect, reasonable probability, reasonable possibility and their associated levels of proof. She concludes that RP remains an elusive concept, much dependant on the specifics of the case. Reasonable prospect may be informed by the concept of turnaround potential when reorganisation is pursued. Having a BRiL outcome as alternative may also cloud the determination, as it seems to be a 'lesser' potential compared to reorganisation.

\section{Definition of key constructs}

Reasonable prospect in this paper refers to a value judgement (not different to that in a business model evaluation) according to Morris, Schindehutte and Allen (2005) but of a distressed business' potential to be reorganised towards solvent operation. RP is thus used to "trigger" the commencement of the process to turn the business around by identifying the minimum requirements informing such judgement. The fact that both objective (rational and factual), as well as subjective criteria, are involved clouds the clarity of arriving at such a judgement. The subjectivity of the observer is not questioned but rather an attempt is made to "quantify" the subjectivity for generalisation. In this study, the observer refers to "an intelligent and honest man, a member of the class concerned and acting in respect of his interest" (Klopper \& Bradstreet, 2014:563 quoting Maughan, J In re Dorman Long Ltd [1994 .Ch 635] p 659).

In this paper, I am mainly interested in the establishment of RP associated with rehabilitation or reorganizing (S128(1)(b)) of a distressed venture rather than pursuing the alternative provided for in S128(1)(b)(iii) of pursuing a better return than in immediate liquidation (BRiL) provided for. Therefore its focus addresses the potential to turn the business around rather than doing a "wind down" although this second option is not eliminated from the decision making through mutual exclusiveness.

Reasonable prospect, however, has to be determined while the business operates in the ZoI. It assists in 'choosing future action' possibilities (Baumard \& Starbuck, 2005:283). The next section explores the ZoI as a construct in more detail.

\section{Zone of Insolvency (Zol)}

There appears to be a growth in the focus on pre-insolvency procedures worldwide. During these informal procedures, action is required when there is sufficient proof of distress, but the venture has not reached an insolvent state yet. All signals, however, indicate that it is about to happen and therefore the 'zone' concept to encapsulate the concept otherwise known as 'environmental scarcity (Schmitt, Barker, Raisch \& Whetten, 2015). The ZoI is a known term in the legal literature but less used in finance and business literature, probably because of its nature when described as imprecise. Judging within the ZoI is negatively influenced by data integrity, asymmetry of information and observer characteristics. Nadkarni and Barr (2008:1398) associate it with using unstable and unanalysable environments.
In search of understanding, the ZoI is defined as an imprecise construct (Barondes, Fairfax, Hamermesh \& Lawless, 2007). The ZoI has previously been explained as 'a blind person looking for a black cat in a dark room that is not there'. Perhaps, the inability to define the ZoI clearly is its main characteristic - being an indefinable place of 'uncertainty and ambiguity' which is unclear and can mostly be identified retrospectively only. Despite this difficulty, the ZoI is widely used in the law literature.

I use ZoI as it ultimately conveys the associated uncertainty and ambiguity surrounding distressed ventures, thus describing the context dimension. The $\mathrm{ZoI}$ is preceded by the so-called 'twilight zone' where the debtors (directors) are at risk as they may become aware (or not) of decline based on vague early warning signals. The twilight zone suggests that the business is nearing the ZoI (entering the vicinity of insolvency (Bainbridge, 2006;282)). Barondes et al. (2007) states that the zone of insolvency occurs when "the company cannot generate and/or obtain enough cash to pay for its projected obligations and fund its business requirements for working capital and capital expenditures with a reasonable cushion to cover the variability of its business needs over time" (p. 235). The ZoI is distinctly different to strategic renewal situations (Floyd \& Lane, 2000) where management has several choices to respond to evolutionary change by applying innovative strategies in going concerns. The ZoI is archetypally characterised by a shortage of resources for basic business performance.

Of course, poor management is generally unable to notice the associated risk signals as venture failure is largely ascribed to poor management as a cause. Often banks (as creditors) are able to identify distress before management of the debtor organisation. The ZoI may overlap several phases of a business such as going concern, decline, distress and eventual failure, again its indefinability being its main characteristic. Principally, the deeper the venture sinks into the ZoI, the less probable it becomes to turn around or reorganise the business to solvency. Finding reasonable prospect remains a challenge.

\section{Affordance theory and resource based theory (RBT)}

I use the dual lens of affordance theory as informed by the resource-based view (RBV), to frame the development of the key elements of the proposed affordance framework.

\section{Affordance theory}

The theory of affordances was introduced by Gibson J.J. (1979) as ecological approach to perception and is chosen as the main lens of this study. It suggests that an environment affords to an animal certain provisions (both good and bad) for functioning within it such as living, running, mating and other actions. The environment thus affords animals such "necessities for existence" such as terrain, shelter, tools, and other animals (Gibson, 1988:4). Like a rock face that affords to a lizard movement, concealment, protection, social interaction and more as habitat while the same is not necessarily afforded to the elephant. Sanders (1997:99) 
confirms affordances as opportunities (beneficial) or dangers (injurious) for actions by animals because of their presence in the environment.

However, affordances are not something "out there" as a characteristic of the environment (Sanders, 1997:105) suggesting "effectivity" to exist between environment and animal. Chemero (2003:181) postulates that affordances are relations between abilities of animals and features of the environment stating that "affordances are both real and perceivable but are not properties of either the environment or the animal". Referring to the lizard above, effectivity suggests that the features of its body relate to the affordances it receives from the rock face, and not so for the elephant with other bodily features. The complementarity of the relation is therefore as important (Sanders, 1997:103). He also argues that the opportunities contain objective and subjective elements contained within the opportunities afforded.

Expanding the theory of affordance, niches are used to describe sets of affordances that may originate from a specific environment. Cameron and Zammuto (1983) also applied niches to classify environments under conditions of decline. The individual affordances may interact and may be complementary when describing the relation between environment (with its possibilities) and the animal with its characteristics. Demir (2015:125) proposed that affordances may appear as bundles. These bundled affordances may be multiple spatiotemporally distinct, yet co-performing action possibilities offered to strategists to act upon. The meaning and value of an affordance for the strategist (as observer) is realised once it has been detected and used since the information residing in affordances has come to the attention of the observer and thus co-presents with his or her motivations (Gibson, 1997).

Gibson (2000:53) proposes that the information for affordances is found in events, both external and internal within the perceiver. She refers to it as "invariant information" that specifies properties of the layout of the environment. Hence, she suggests the importance of studying the events.

Stoffregen (2000:4) further proposes that events also have affordances but is not an affordance in itself. Chemero (2000:39) defines events as "changes in the layout of affordances of the animal-environment system". A fire, for example, is an event with different affordances depending on the properties of the animal (think tortoise vs. bird). Considering bundled affordances further assists one to consider the event as the locus of invariant information that prompts behaviour (Demir, 2015) of an observer. He further proposes that the "meaning and value of an affordance for an observer is realised once it has been detected and used since the information residing in affordances has caught the observer's attention and thus co-presents with his or her motivations".

Finally, Gibson (2000:54) states that environments provide (afford) resources or supports that an animal may (or may not) attend to use. The information for an affordance is, therefore, to be found in events that include the relevant environmental features, the activity of the organism, and the consequences that ensue as well as the relations among these.

The similarity of resource munificence and affordance includes both rational resources and subjective resources in the format of a bundled affordance. I now attempt to superimpose the affordance theory onto the business in distress, operating in the ZoI. I suggest that the ZoI affords the business potential future actions (Demir, 2015:138) to pursue. Thus:

If animals are afforded potential actions by its environment, Then: in the same way:

$\rightarrow$ Businesses are afforded potential actions (based on munificence) by the business environment it operates in.

Sheppard and Chowdhury (2005:240) suggest that decline and failure are not typically the fault of either the environment or the organisation, but it rather must be attributed to both of these forces, thus confirming effectivity (Sanders, 1997:105). This may confirm that the alignment of the business model elements is required to determine if reasonable prospect may or may not exist.

Application of affordance theory to business rescue suggests that arrival in the ZoI is an event (environment) that may afford the business (based on the observer view) of the information about resources as affordances available for RP determination. However, as stated, the observers consist of BRPs, shareholders, creditors, debtors, employees and even courts and therefore, diverse views exist. Each observer obtains different affordances from the event based on their own properties. The research, therefore, seeks to understand what the ZoI may afford the business regarding reasonable prospect, thus, the potential future actions described by an RP determination. This may assist decision makers of RP in two ways namely: firstly, by making sense of how the ZoI can be interpreted and secondly improve understanding of RP determination to enhance factual determination across observers.

Much of affordance theory implies the role of resources in affordance. Therefore, RBT is considered as the second lens.

\section{Resource-based theory (RBT)}

While BR has been investigated from both "theory of the firm" and "stakeholder theory" perspectives (Ho, 2008), I choose "resource-based theory" as the support lens of this study. McCann (2007:7) confirms scarcity of resources together with compression of time as key to turnarounds with Schmitt et al. (2015) framing it as environmental scarcity. Thus, the resource-based view (RBV) supports the business decisions associated with the rescue event. While the proposed affordance framework acknowledges the firm and stakeholder theories are important, the resources available in the ZoI is crucial to the opportunity judgement, similar to when a start-up opportunity is evaluated by venture capitalists. Thornhill and Amit (2003:497) suggest resources 
to include not only assets but also capabilities. Cook, Pandit and Milman (2011:1) similarly apply the resource-based view and the theoretical means to assess the viability of bankrupt SMEs. Guha (2016:93) incorporates the resource view through addressing it from the "organisational slack" viewpoint in declining firms. Finally, Trahms, Ndofor and Sirmon (2013) recognise the importance and complexity of resource based actions in response to turnaround situations. Barker and Mone (1998:1233) frame it as a 'superior or inferior' resource argument that exist in the turnaround situation.

Approaching it from the resource allocation perspective, Castrogiovanni (1991) already amplified the role of environmental munificence as resource scarce or abundant environments in which businesses operate. According to him these environments operate according to levels of specificity, immediacy and relevance to the organisational phenomenon of interest. Operating in the ZoI typically suggests operating under conditions of scarce resources. Pretorius (2008) also incorporated Castrogiovanni's munificence extremes in modelling turnaround situations and strategies.

Chesbrough (2007:12) expounded the concept of the business model to determine creating value and generating revenue as the aggregate actions of the business. These are specifically useful as it guides the specific activities which make up the business model (Rezazade-Mehrizi \& Lashkarbolouki, 2016). Relevant for this paper is the view that reasonable prospect elements overlap with the elements of the business model that exists at the position within the ZoI. Morris, Schindehutte and Allen (2005:726) propose the importance of the business model as even adequate resources may not be sufficient for overcoming failure. They, therefore, acknowledge the elements of capabilities and competencies as inputs to the business model. Madrid-Guijarro, Garcia-Perez-de-Lema and Van Auken (2014:160) contend that the resource-based view considers the environmental impact on distress as more than that of firm-specific factors. They considered specifically the relationship to non-financial factors.

The reasonable prospect determination, therefore, seems to depend on how observers view the internal resources and environmental conditions and requirements for the appropriate business model elements during the turnaround situation. Eisenhardt and Schoonhoven (1996:138) suggest that resources give firms a cushion to weather business downturns and other setbacks. These interpretations are based on both objective and subjective measures. I now expand on the subjective component of the evaluation as a vehicle for the development of the framework and explore the link with RBT.

\section{Turnaround situations and positions}

Literature reports the use of various categorizing variables to describe decline conditions (Cameron \& Zammuto, 1983), preconditions (Cameron, Whetton \& Kim, 1987), turnaround matrixes (Boyle \& Desai, 1991), decline stages (Weitzel, 1991), turnaround stage models (Robbins \& Pierce, 1992), turnaround situations (Pretorius, 2008) or positions (McCann, 2009) to firstly understand the generic conditions and thereafter address the selection of appropriate strategies. At heart, all these frameworks and models inform higher level sense making of the position that a firm occupies in the ZoI and to inform reasonable prospect and then the resultant strategy choices available. Few of these models could be handed to the BRP with the expectation of practical implementation to inform reasonable prospect.

\section{Objective and subjective contributions to evaluation of RP}

Barker and Barr (2002) expounds the subjective elements of attribution by observers of decline in firms. They explicate the role of causal attribution, beliefs, interpretations and collective interpretations in these judgements. Barker (2005) even extends these to cognitive traps, biases and self-serving causal interpretations in diagnosing organisation failure. My aim is not to dispute their existence and understand these better but purely to acknowledge their existence and their practice role when attempting to encapsulate these within the proposed framework. The three-way interpretation of relevance for RP determination involves that of the TP or BRP, the creditors and the court. The application of affordance theory with the resource-based view acknowledges the interrelationship of environment and observer with the associated subjective elements of the determination.

\section{Research questions}

The research questions to guide the framework development are thus:

1. What are the rudimentary/governing constructs to determine the RP commencement standard?

2. How can the subjectivity of an observer to enhance factual determination of RP for various observers be captured?

\section{Methodology}

The research aims to design and propose a conceptual evaluation framework, firstly, by drawing from affordance theory and informing it by resource-based theory. Secondly, the potential elements of basic business management are expounded into a business model. After that, affordances of RP (Joubert, 2013) elements judged through the chosen lens are explored to inform the framework. Finally, the proposed variables are extracted for categories (positions) within the ZoI (turnaround situations) and presented.

\section{Multiple angles and considerations for RP assessment}

Financial literature is much more concerned with 'level of proof' as the measure used is that of the 'going concern' determination. Based on the historical and projected financial statements and the projected future value of the firm, the going concern value is established. These 'objective' 
assumptions suggest 'trustworthy information', but with businesses in distress, all information and especially financial information suffer severely from 'data integrity' liabilities (Pretorius \& Holtzhauzen, 2008). This then forces the observer also to consider subjective measures based on experience to benefit the judgement.

At this junction, it is useful to distinguish between the concepts of turnaround and rescue, as they may have a material influence on the interpretation of affordances. The distinction between turnaround and rescue contexts is important, as they may differ in properties as events and if so present variations in layouts of affordances (Chemero, Klein \& Cordeiro, 2003) for action. Turnaround is typically associated with earlier intervention (often informal) while rescue is a formal process driven by legal directives for distressed businesses. The appellations of turnaround managers and rescue practitioners, however, are generally used interchangeably, owing to large overlaps in their processes, tasks, activities and functions - especially when the peculiar points of differentiation are not clear at all. However, while their underlying legal support is inherently different, as succinctly described by Mindlin (2013), the ZoI at the initiation of the process is overwhelmingly similar as far as the reasonable prospect determination is concerned.

The venture capitalist perspective suggests that RP determination may be judged based on theory and criteria similar to that as considered when evaluating a 'new venture start-up' as seen in the venture capital literature. A business operates when its business model is achieved within the resource munificence for potential actions in pursuit of opportunity. These include concepts for value creation, selling, appropriating/producing concepts (products or services), profiting and financing of operations all contributing to the eventual business model (Mehirizi \& Lashkarbolouki, 2015) put forward. Complicating these measures from the venture capital literature further suggests that it will also depend on the 'who makes the judgment' on these affordances as well as 'who will be the jockey' for the venture.

In the same way, a firm in financial distress will probably require financial injection, and the question to be answered is if there is potential for a 'venture to exist' once such financial injection is obtained. This leads to evaluating the feasibility of creating a future solvent going concern. Feasibility is closely related to reasonable prospect for a venture. Feasibility typically looks at whether all the ingredients exist for a business to be successfully operated. Typically, these will include demand for the service/product, production capacity to fulfil the projected demand, the profitability of operating the production capacity, cash flow to sustain the operations and any other unique factors that might render the business as unworkable, to name some crucial elements (see also Table 1).

There is a key difference between a start-up and distressed business perspectives. Start-ups typically depend solely on unproven projections while for distressed ventures, a history normally exists that may suggest that things did work out in the past (or not) and that there is a new context influencing the feasibility. Despite the difference, the underlying principle when asking the affordance question is very similar.

Feasibility is generally associated with early stage financing of a venture and in rescue situations with the first creditors meeting. Once determined, the next phase is the viability study (sometimes inter changeably called due diligence) where detailed analysis and verification of the same elements are investigated, determined, interrogated and confirmed, Viability, therefore, requires enhanced accuracy versus the plausibility of the reasonable prospect determination at filing. Viability analysis (Pretorius, 2013) is closely associated with the rescue plan presented for the vote at the second creditor's meeting.

Reasonable prospect determination remains the responsibility of the BRP (S 141) throughout the rescue process. Research on what exactly these BRPs use to make sense and evaluate $\mathrm{RP}$ is scant (Pretorius \& Holtzhauzen, 2013, Janse van Rensburg, 2016) at this early stage after the Act was introduced. There appear no easily applicable "tests" with factual foundations to apply generically. Most of the time, the BRPs are vague on or at least protective of the measurements they use.

I proceed by providing the deductive reasoning leading to an assessment framework that determines/evaluates the RP afforded by the position within the ZoI event. After that, several turnaround situations are presented to improve sense making of the assessed position within the ZoI that the business may occupy.

\section{Reasoning to derive the eventual constructs I measures for the proposed framework}

To formulate a framework with the 'fewest' key measures that are still significant to consider and inform observers is immensely difficult. Collet, Pandit and Saarikko (2014:123) reports 23 variables involved that contribute to success in turnarounds for Finnish firms. Table 1 proposes the constructs and measures required for determining the minimum elements for the business model. I start with the basic requirements for a going concern (as benchmark) and then compare that with different turnaround situations and special cases that may highlight specific context elements from the ZoI. Eight "ZoI scenarios" are then presented with data points for each. Each of the proposed measures is also discussed through reasoning for sense making and proposal in the framework. While the proposed assessment framework can never claim to be flawless, its underlying value is that of practical applicability.

It is important to acknowledge at this point that the paradox (Handy, 2009:17) facing the 'affording' observers as decision makers involves the requirement for a few key measures to inform the commencement standards but at the same time such measures are made up of a myriad of antecedent variables which may or may not, detrimentally affect their observations. At this early junction, I present the reasoning to 
guide the discussion of the proposed framework (See also Table 1 and Figure 1). Applying affordance theory to business in distress is proposed as follows:

The RP bundle of resource affordances and the properties thereof require its further investigation and is presented as:

$$
R P=\int \text { affordance }_{1} x \text { affordance }_{2} x \ldots \ldots \ldots \text { affordance }{ }_{n}
$$

where these affordances are the resource requirements for a business to enable return to operating as a solvent entity. The investigation now turns to the assessment framework which is proposed by this study. Thus:

$$
\mathrm{RP}=\int[a D+b A C+c P M+d L F] x e F C \times f R C \times g(1-R E)
$$

where

$\mathrm{RP}=$ Reasonable prospect; $\quad \int=$ function of; $\mathrm{D}=$ Demand for selling the concepts; $\mathrm{AC}=$ Appropriation capacity for the concept; $\mathrm{PM}=$ Profit model; $\quad \mathrm{LF}=$ Liquidity and financing model; $\quad \mathrm{FC}=$ Fatal caveats; $\mathrm{RC}$ = Rectifiable caveats influencing performance; $\mathrm{RE}=$ Risk and error; $\mathrm{a}-\mathrm{g}=$ constants determining level of judgement.

Thus: going concern businesses are afforded (by its resource environment) most actions that are required to operate on a solvent basis and being successful based on equation 2. Each of these is shortly explored later to substantiate the relevance of each affordance for the RP equation.
But: When a business is operating in the ZoI, I argue that: The distressed business is afforded limited resource actions to return to solvent operation. One or more of the equation determinants (variables) are at an inferior resource level of the RP commencement standard when benchmarked with the going concern.

The interest is thus to describe the potential business actions (as a bundled affordance for RP) to return to solvency that is afforded by the ZoI [or not] for the specific business. This requires the determination of a "commencement level" from which one could judge the turnaround potential.

In order to return a distressed business to operate as a solvent going concern, the entity must be capable to sell some or other concept to customers (thus demand must exist). To do this, it, therefore, requires the operational capacity for appropriating (producing or accessing from its network) the concept at profit levels that allows for "sensibly" financed operations and eliminating any circumstance that may render its operation ineffective and inefficient. Thus, all the above are considered resources or being made up by resource elements - together as a bundled affordance. Translating this to the proposed framework, it appears as shown in Table 1 as the constructs, measures, antecedent indicators, reasoning and eliciting questions as well as potential sources to inform the measures. The rest of this section now expands the individual constructs briefly for the bundled affordance to determine RP. Each affordance is shortly described supported by its antecedents and potential metrics to guide assessment.

Table I: Application of the reasonable prospect assessment (RPA) score for different turnaround situations when

\begin{tabular}{|c|c|c|c|c|c|c|c|c|c|c|}
\hline \multirow{2}{*}{$\begin{array}{l}\text { Business } \\
\text { Categorization }\end{array}$} & \multicolumn{7}{|c|}{ Affordance scores allocated } & \multirow[b]{2}{*}{$\begin{array}{l}\text { Max Score } \\
\text { (Multiply) }\end{array}$} & \multirow[b]{2}{*}{$\begin{array}{c}\text { Log } \\
\text { score }\end{array}$} & \multirow[b]{2}{*}{$\mathrm{RPA}$} \\
\hline & $\mathrm{D}$ & $\mathrm{AC}$ & PM & LF & $\mathrm{FC}$ & $\mathrm{RC}$ & $\mathrm{RE}$ & & & \\
\hline Optimal performance & $4^{\mathrm{a}}$ & 4 & 4 & 4 & $1^{\mathrm{b}}$ & 4 & 0.01 & 1013.76 & 3.01 & 63.4 \\
\hline Going concern & 3 & 3 & 3 & 3 & 1 & 3 & 0.01 & 240.57 & 2.38 & 35.6 \\
\hline Perform well & 4 & 3 & 3 & 2 & 1 & 3 & 0.2 & 172.8 & 2.24 & 28.8 \\
\hline Under performing & 3 & 2 & 2 & 2 & 1 & 3 & 0.3 & 50.4 & 1.70 & 18.9 \\
\hline Strategic distress & 2 & 2 & 2 & 2 & 1 & 2 & 0.4 & 19.2 & 1.28 & 9.6 \\
\hline Generic distress & 2 & 2 & 2 & 2 & 1 & 2 & 0.5 & 16 & 1.20 & 8.0 \\
\hline Crisis & 1 & 2 & 1 & 1 & 1 & 1 & 0.5 & 1 & 0 & 2.5 \\
\hline Fatal Caveat & 1 & 2 & 1 & 1 & 0 & 1 & 0.1 & 0 & 0 & 0.0 \\
\hline \multicolumn{10}{|c|}{ Scoring: Judgments from observers } & \\
\hline \multicolumn{10}{|c|}{${ }^{\mathrm{a}}$ Clear path to best-envisioned endpoint $(4)=$ confirmed future existence, sustainable } & \\
\hline \multicolumn{10}{|c|}{ Healthy status with potential path $(3)=$ Currently exist, assumed future existence under proper management } & \\
\hline \multicolumn{10}{|c|}{ Questionable and unclear path $(2)=$ Currently danger levels, doubtful, improbable, (Quantify in RE) } & \\
\hline \multicolumn{10}{|c|}{ Absent $(1)=$ Non-existing path or beyond fixing } & \\
\hline \multicolumn{10}{|c|}{ Risk and Error - Doubt/Uncertainty about accuracy of factual information at the decision point (ex. $0.2=20 \%$ risk to fail) } & \\
\hline \multicolumn{10}{|c|}{${ }^{b}$ Fatal caveat: Exist $=0$, None $=1$} & \\
\hline RPA Score & \multicolumn{9}{|c|}{$\mathrm{RP}=\int(\mathrm{aD}+\mathrm{bAC}+\mathrm{cPM}+\mathrm{dLF}) \times \mathrm{eFC} \times \mathrm{fRC} \times \mathrm{g}(1-\mathrm{RE})$} & \\
\hline
\end{tabular}
operating in the ZoI 


\section{Resources affording the selling action}

Selling firstly requires a demand for its concept from willing customers capable of paying. When a venture experiences strategic distress or crisis (Pretorius, 2008) as turnaround situation, it typically faces externally induced loss of demand due to shifting needs of customers for reasons of innovation, technology, alternative options and more. When facing underperformance, sufficient demand still exists, but its appropriation is typically inefficient. The question is whether concepts could be sold and at what level for income generation? Selling, therefore, depends on demand and competitiveness in the industry as well as the target markets pursued. Typically, the indicator used is sales and sales revenue for the past six months ( $\mathrm{t}-0.6$ in Table 1$)$ to answer the question if demand exists and at what level? Future prediction of sales is also relevant. The level of existence is based on the business model.

\section{Resources affording the appropriating action}

Appropriating the concept for selling potentially involves, producing, accessing, insourcing or any action as part of the capacity based on the business model. Of relevance is especially the value of an ongoing business operation versus non-operating business for judgement of appropriating capacity where closed down operations afford little evidence for future business. The capacity elements involve facilities, finance, human resource and network capacity.

\section{Resources affording the profiting action}

Assessing that selling and appropriating can be performed, the profitability of doing so needs to be evaluated. This judgement depends on pricing, margins, volumes, fixed and variable cost allocations and more. Ratio analysis of operating finance may inform this assessment. It is not unheard of that businesses are found to have operated on negative profit margins - for various reasons. Typically these judgements require industry comparisons to relatively assess the levels of operation, much like for all the affordances.

\section{Resources affording the financing action}

A business in the ZoI and that filed for business rescue implies it is in financial distress (S 128(1)f) as it cannot pay its dues currently or is projected to be unable to do so in the next six months. The injection of post-commencement financing $(\mathrm{PCF})$ to overcome this illiquidity (and potentially address insolvency) is, therefore, a crucial element in any turnaround. Internal financial slack is mostly non-existing or in short supply. The absence of post-commencement investment is often incorrectly blamed as a cause for unsuccessful business rescues (Pretorius, 2015). External financing depends heavily on the selling, appropriating and profiting assessments and the perception of a bundled affordance of RP for a workable business model.

\section{Resources affording the eliminating action}

Businesses enter the ZoI for various reasons which may include those referred to as "fatal caveats". These may involve circumstances such as changes in the legislative environment, legal cases against the venture, freak accidents, political intervention and more which Garg, Walters and Priem (2003) associated with the general (opposed to the task) environment. Anecdotally, a recent example of a mine incident where three unrecoverable bodies in a mine shaft after an accident turned out to be such a caveat. Operations ceased. The minister declared that the mine would not be allowed to operate from a new shaft unless the bodies are recovered first from the current shaft. The cost involved in the immediate recovery (estimated as 7 times the cost of a new shaft) was so extensive that all potential investors of the needed post commence funds just disappeared. The result is insolvency as the mine needed to operate first (appropriate) and then address the recovery with operational revenue. These caveats are often from an external origin and are not necessarily the fault of the business itself. The question is whether it can align itself with the changed environment to achieve the minimum requirement for RP.

\section{Resources affording the overcoming actions}

Often caveats develop that may hinder the performance of the appropriation process. These may involve lesser inefficiencies, cost creep, asset [under]utilization, failed new product lines, productivity, product quality and more. Overcoming such specifics require the identification of the specific caveat and perceiving the means to overcome it. Typically the resources here involve innovation, creativity, management capacity and other competences.

\section{Resources affording the mitigating of risk and uncertainty actions}

Two key risks are asymmetry of information and liability of data integrity which are mainly associated with the early stage of the intervention where the RP determination is required. Less certainty means more risk towards all the previously mentioned actions. No viability and diligence process has started, and the uncertainties are many. Often rescue processes are deliberately used to manipulate the environment for various reasons (abuse) not part of this paper.

\section{Resources as a bundle affording Reasonable Prospect or not}

Table II suggests the key eliciting questions associated with each of the affordance requirements. These questions are especially important for their contribution to increase learning (Cannon \& Edmondson, 2005:307) and improve sense making and reach a point where the observer can make a decision. While there may exist some hierarchy of the affordances, all must play its role in the bundled affordance. 


\section{Findings on application of the affordance framework}

In this section, a framework that includes reasonable prospect assessment (RPA) scores is presented where observers can 'quantify' their assessments on each of the resource affordances in equation 2. The scales are mainly 4-point scales (to eliminate unsure as a category), one binary (yes-no) scale and one percentage determination scale to force direction towards prospect (or not). Each situation (scenario) refers how a neutral observer would typically judge it.

Table 1 and Figure 1 propose the RPA scoring and outcomes of the scenario assessments respectively by using eight distress categorisations constructed for this study: four are based on turnaround situations in the ZoI (performing well, underperformance, strategic distress and crisis) relative to two solvent categorisations (Optimal performance and going concern) and two insolvent categorisations (Generic distress and fatal caveat). Each is informed individually. The scores allocated are based on hypothetical assessment allocations to demonstrate the score interpretations for each. This serves as a progression as the RP improves.

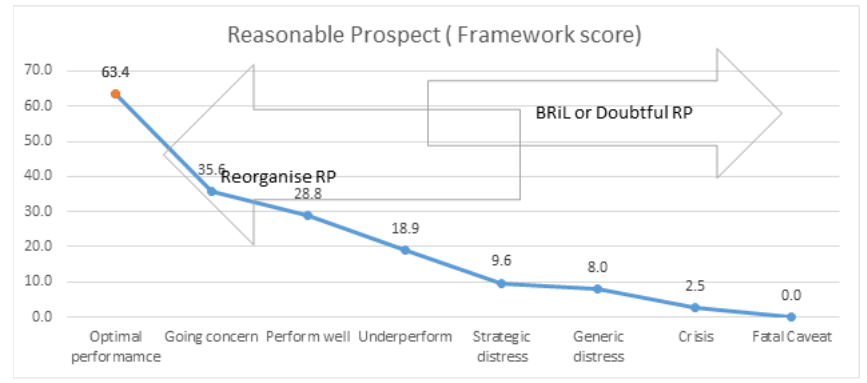

Figure I: Reasonable prospect assessment with RPA scores to guide assessment

Optimal performing businesses are scored on maximum possible performance (scores $=4$ ) to establish the upper end of the score where a clear path to future performance is visible. There are no fatal caveats nor rectifiable caveats, and the risk is judged as low (See Table 1 ratio $=0.01$ that suggests $99 \%$ accuracy) based on reliable management information. Observers assess the resources as optimal with an RPA score of 63.4 that is the maximum possible score.

Going concern businesses were scored at performance level 3 for the different affordances which propose a current healthy status where a potential path to future performance is visible. There are no obvious fatal caveats but minor rectifiable (performance) caveats may be visible, and the risk is judged as manageable based on reliable management information. Observers assess the resources as healthy to operate as a going concern with an RPA > 35.6 that is the bottom of this category.

Businesses in generic distress is a hypothetically created category purely to complete the picture in Tables I and II. Assessments of individual affordances are mostly at level 2 to force unclear context and questionability. The framework's value is to establish the approximate score between strategic distress and crisis.

Fatal caveat businesses as a category suggest that despite the existence of the afforded resources, no matter the level, there is no reasonable prospect. Figure 1 gives broad category scores for a reasonable prospect.

\section{Turnaround situations to describe the ZoI}

Four turnaround situations as described by Pretorius (2008) are used to demonstrate the assessment framework. Each category is used to depict the variations associated with ZoI to show the use of the measures.

A performing well businesses may face short-term distress for various reasons which often include spiking demand and pressured finance. Scores vary slightly compared to the going concern evaluation. Short term illiquidity (a.r.o overtrading in response to demand) may appear and is typically the origin of the problem. A current healthy status where a potential path to future performance can be supported (solvency assumed). There are no fatal caveats yet, but minor performance caveats may appear while the risk is judged as manageable based relatively easy access to external funding. Observers assess the resources as healthy to operate as a going concern despite the short term problem. Distress in such business is often addressed by management intervention and financial restructuring only. An RPA score of 28.8 guides this evaluation with turnaround a real possibility.

Underperforming businesses typically face distress because of poor operations and resource scarcity. Distress is especially visible in appropriation, profit margins and liquidity to fulfil the demand (which is healthy). Individual affordance scores, typically are at level two suggesting an unclear path where a lower future performance is anticipated. There are still no fatal caveats, but minor performance caveats may be appearing while the risk is judged as manageable based relatively easy access to internal slack or external funding. Observers assess the resources as risky to maintain operating as a going concern despite the appropriating problems. Risk and error are on the increase, but TPs and BRPs generally appear at ease with fixing these problems. An RPA score of 18.9 indicates the reasonable prospect for a turnaround at the approximate bottom level.

Businesses in strategic distress typically face distress as a result of lost demand despite operations and potential resource abundance. Distress is especially in appropriation overcapacity leading to reduced profit margins and liquidity a.r.o adverse demand. Scores are at 'level two' suggesting an unclear path where a lower future performance is anticipated despite the capacity to appropriate. There are still no fatal caveats, but performance caveats may appear while the risk is judged as manageable based relatively easy access to internal slack or external funding. Observers assess the risk as external to the business despite the appropriating capacity. The risk is on the increase, and TPs and BRPs generally appear concerned when facing demand problems. An RPA of 9.6 suggests little opportunity for a turnaround. 
Table II: Criteria for evaluation when determining reasonable prospect commencement standard of a business operating in the zone of insolvency

\begin{tabular}{|c|c|c|c|c|c|}
\hline $\begin{array}{l}\text { Construct } \\
\text { (Affordance) }\end{array}$ & Measure & $\begin{array}{l}\text { Antecedent } \\
\text { indicators }\end{array}$ & $\begin{array}{l}\text { Reasoning and questions to elicit } \\
\text { determination }\end{array}$ & $\begin{array}{l}\text { Sources and } \\
\text { time frames } \\
\text { of info } \\
\end{array}$ & References \\
\hline $\begin{array}{l}\text { Selling the } \\
\text { concepts }\end{array}$ & $\begin{array}{l}\text { Demand } \\
\text { (4-point } \\
\text { scale) }\end{array}$ & 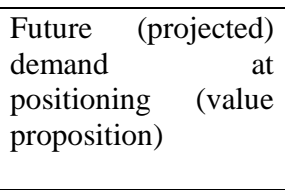 & $\begin{array}{l}\text { Opportunity to sell is the trigger for } \\
\text { business existence. Originate in the } \\
\text { strategic environment. } \\
\text { Q: Is there a future demand for the } \\
\text { concept? If so, at what level? }\end{array}$ & $\begin{array}{l}\text { Sales } \\
\text { revenue for } \\
\mathrm{t}-0.6^{\mathrm{a}} \text { mo }\end{array}$ & $\begin{array}{ll}\text { Hofer } & (1980: 20), \\
\text { Timmons } 1999: 119), \\
\text { Nadkarni \& Barr } \\
(2008: 1406) .\end{array}$ \\
\hline $\begin{array}{l}\text { Appropriating } \\
\text { the concepts }\end{array}$ & $\begin{array}{l}\text { Capacity to } \\
\text { appropriate } \\
\text { (4-point } \\
\text { scale) }\end{array}$ & $\begin{array}{l}\text { Ongoing operation, } \\
\text { HR } \quad \text { capacity, } \\
\text { competency, } \\
\text { network, supply } \\
\text { chain, Alignment } \\
\text { and matching. }\end{array}$ & $\begin{array}{l}\text { To satisfy the demand, the concept must } \\
\text { be appropriated through the business } \\
\text { model. } \\
\text { Q: Does the capacity exist to appropriate } \\
\text { the concept? At what level? }\end{array}$ & $\begin{array}{l}\text { Business } \\
\text { model for } t, \\
t+1, \\
\text { Resignations }\end{array}$ & $\begin{array}{l}\text { Hambrick \& Schecter } \\
(1983: 232), \\
\text { Sudarsanam \& Lai } \\
\text { (2001:185), Nadkarni } \\
\text { \& Barr (2008:1406). }\end{array}$ \\
\hline $\begin{array}{l}\text { Profiting } \\
\text { from } \\
\text { business } \\
\text { model }\end{array}$ & $\begin{array}{l}\text { Profit and } \\
\text { cost model } \\
\text { (4-point } \\
\text { scale) }\end{array}$ & $\begin{array}{l}\text { Profitability } \\
\text { measures (RoA, } \\
\text { Asset turnover, RoE, } \\
\text { EPS), Cost of BR } \\
\text { itself, }\end{array}$ & $\begin{array}{l}\text { Given the demand and appropriability, } \\
\text { Q: can this be achieved profitably based } \\
\text { on margins and relative costs? }\end{array}$ & $\begin{array}{l}\text { Margins and } \\
\text { profitability } \\
\text { ratios, } \mathrm{t}-1, \mathrm{t} \text {, } \\
\mathrm{t}+1\end{array}$ & $\begin{array}{l}\text { Hofer (1980:27), } \\
\text { Castrogiovanni, } \\
\text { Baliga \& Kidwell, } \\
\text { 1992:28). }\end{array}$ \\
\hline $\begin{array}{l}\text { Financing the } \\
\text { model }\end{array}$ & $\begin{array}{l}\text { Liquidity } \\
\text { and } \mathrm{C} / \mathrm{F}(4- \\
\text { point } \\
\text { scale) } \\
\text { position }\end{array}$ & $\begin{array}{l}\text { Resource } r \text { slack, } \\
\text { Liquidity measures } \\
\text { (current and quick } \\
\text { ratios), Distress } \\
\text { definition, Working } \\
\text { capital requirement }\end{array}$ & $\begin{array}{l}\text { To profit requires variant cash } \\
\text { requirements which must be achieved } \\
\text { through outside funding, So } \\
\text { Q: Can this funding be obtained at } \\
\text { liquidity requirements to overcome } \\
\text { deficiency periods? }\end{array}$ & $\begin{array}{l}\text { Financial, } \\
\text { bankers } \\
\text { tests, } \mathrm{t}, \mathrm{t}+1\end{array}$ & $\begin{array}{l}\text { Francis \& Desai } \\
(2005: 1207), \text { Van der } \\
\text { Linde (2008), Bryan } \\
\text { et al. (2011:7), } \\
\text { Pretorius \& Du Preez } \\
\text { (2013), Conradie \& } \\
\text { Lamprecht (2015). }\end{array}$ \\
\hline $\begin{array}{l}\text { Eliminating } \\
\text { the obstacles }\end{array}$ & $\begin{array}{l}\text { Fatal } \\
\text { caveats } \\
\text { (binary } \\
\text { scale) }\end{array}$ & $\begin{array}{l}\begin{array}{l}\text { Insolvent balance } \\
\text { sheet (claims), }\end{array} \\
\text { Technology } \\
\text { relevance, External } \\
\text { Origin of cause, } \\
\text { Legal, Management } \\
\text { culture, Abuse of } \\
\text { process, fraud, Any 0 } \\
\text { (zero), }\end{array}$ & $\begin{array}{l}\text { Despite the above basic components, } \\
\text { there are technical factors that may render } \\
\text { the business model worthless or not } \\
\text { feasible (ex. Pending Lawsuit, industry } \\
\text { weakness and radical innovations). } \\
\text { Mostly has its origin in the strategic } \\
\text { realm. Process abuse motives, Typically } \\
\text { acute rather than chronic in nature. } \\
\text { Q: Do any fatal caveats exist? }\end{array}$ & $\begin{array}{l}\text { Business } \\
\text { specific } \\
\text { future } \\
\text { projections, } \\
\mathrm{t}, \mathrm{t}+1\end{array}$ & 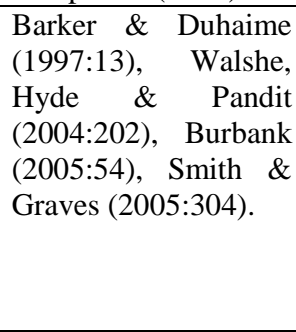 \\
\hline $\begin{array}{l}\text { Overcoming } \\
\text { performance } \\
\text { barriers }\end{array}$ & $\begin{array}{l}\text { Rectifiable } \\
\text { caveats }\end{array}$ & $\begin{array}{l}\text { Insolvency ratios, } \\
\text { Creditor vote, } \\
\text { Internal Origin of } \\
\text { cause, } \\
\text { dependence PCF } \\
\text { (external slack), Sale } \\
\text { dependent } \\
\end{array}$ & $\begin{array}{l}\text { Some caveats are not fatal but may limit } \\
\text { performance, therefore can be rectified } \\
\text { through business practices (ex. New } \\
\text { competitor, ageing machinery). } \\
\text { Q: What are these caveats? Can they be } \\
\text { rectified? }\end{array}$ & $\begin{array}{l}\text { Industry } \\
\text { reports, } \\
\text { trend } \\
\text { analysis, }\end{array}$ & 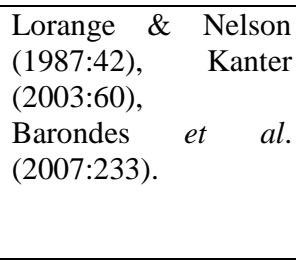 \\
\hline $\begin{array}{l}\text { Mitigating } \\
\text { risks and } \\
\text { errors }\end{array}$ & $\begin{array}{l}\text { Risk and } \\
\text { error } \\
\text { (Accuracy } \\
\text { judgment } \\
\text { as a } \\
\text { percentage } \\
\text { expressed } \\
\text { as ratio) }\end{array}$ & $\begin{array}{l}\text { Asymmetry of } \\
\text { information, } \\
\text { Liability of data } \\
\text { integrity, Rescue } \\
\text { assumptions, } \\
\text { Management, } \\
\text { Investment risk, } \\
\text { Solvency ratios, } \\
\text { Debt ratio, Interest } \\
\text { cover, Evolving } \\
\text { nature - time } \\
\text { relationship, BRP, }\end{array}$ & $\begin{array}{l}\text { During the process, the decision-making } \\
\text { is at risk a.r.o. Asymmetry of information, } \\
\text { Lack of data integrity, assumptions and } \\
\text { associated risk for alternative initiatives. } \\
\text { Q: can these be quantified and rectified to } \\
\text { the satisfaction of the creditor voting } \\
\text { body? }\end{array}$ & $\begin{array}{l}\text { Current } \\
\text { situational } \\
\text { questions }\end{array}$ & $\begin{array}{l}\text { Preston (1986:521), } \\
\text { Fredenberger } \quad \text { \& } \\
\text { Bonnici (1994:60), } \\
\text { Cannon \& Edmonson, } \\
\text { 2005:313), Mellahi, } \\
\text { 2005:263), Calandro } \\
(2009: 23) \text { Nadkarni } \\
\text { \& Herrmann, } \\
(2010: 1060), \quad \text { Stovall } \\
\text { \& Brodsky (2013:10), } \\
\text { Baldiga (2014:116). }\end{array}$ \\
\hline
\end{tabular}

${ }^{\mathrm{a}} \mathrm{t}-6=$ time depicting 6 months before, $\mathrm{t}=$ Current (now) and $\mathrm{t}+1=1$ year into future

Businesses in crisis typically face the same environment as those in strategic distress but more severe circumstances such as complete loss in demand leading to limited operations (severe under capacity) and resource scarcity. Distress is clearly visible especially in appropriation overcapacity leading to crashing profit margins and severe liquidity problems. Crisis is a severe case of strategic distress. Scores are at 'level one' suggesting an absence of a path to rectify problems. Fatal caveats can now appear and alternative strategies (Defensive mergers, business or unit sales, BRiL and other options) become relevant. Performance caveats are everywhere, and the risk is judged as high based on limited operations and no access to internal slack or external funding. Observers assess the causality as external to the business 
despite the appropriating capacity. An RPA score of 2.5 suggests virtually no opportunity for turnaround.

Any businesses with a fatal caveat is not saveable as the score of zero shows.

\section{Conclusions}

Rescue practitioners are required to convince the creditor body by their "factual" reasoning that RP exists at the first creditors meeting. The value of the affordance framework is therefore firstly to inform the creditors' first vote for support, but it also has value for the compilation of the rescue plan. Application via the court procedure may also benefit from and informed use of the affordance framework although only time will tell if this may be considered by the relevant judges applying their discretion to it.

While assessments are expected to vary depending on the observer (animal), the framework provides a useful conversion of both subjective and rational information for evaluation of firms operating in the ZoI. The turnaround situations also assist in the sense making of the relevant RPA scores. While the research cannot claim full transparency in the ZoI, the framework provides boundary conditions that could guide decision making. The fact that the framework provides for assessment during the absence of data integrity and information asymmetry by allowing subjective judgement makes it useful for practical application.

\section{Implications for the rescue industry}

Factual determination of RP, as demanded by the courts, will probably remain problematic in the business rescue industry. The RPA score presents a definitive starting point for practitioners to pursue the initial evaluation of RP. At least, the RPA score can serve as a guideline for different parties (directors, shareholders, creditors and employees) to support the reorganisation process (or not) and thereby address the conflict (Pretorius, 2015) within the growing industry. It could create a point of departure for negotiation.

It is also likely that the RPA score may assist practitioners in overcoming the asymmetry of information and data integrity liabilities as associated with business rescue events. This has value for all stakeholders.

\section{Limitations and further research}

The first limitation of the proposed framework is its conceptual nature and design that was subject to my own observer perceptions and experiences in the practice of turnaround. Its dependence on the subjective components of affordances is real. I attempted addressing this by leaning heavily on the theory and literature, but still, it should be considered, and therefore future research will apply the framework to a sample of collected business rescue plans to evaluate the RP before and after implementation of the plan, thereby seeking validity for the framework.
The potential for an individual affordance to be "double counted" in the assessment/calculation of the RPA should be noted. For example, if future liquidity depends on a "nonexisting' PCF provider, it may happen that it is considered again under either the fatal caveat category or under the risk and error of the event category. It is, however, conceivable that it may rather constitute a framework strength when one considers its sensitivity to such factors of relevance.

The third limitation may be the dependence on anecdotal cases to construct the framework which rather highlights the irregular and unexpected appearances of information for substantiating reasonable prospect. Trustworthiness, validation and repeatability needs to be sought in future research as the framework is not intended to serve as a viability study or replace due diligence type analyses. Future research should also consider actual elements used by practitioners when they judge the affordances of a turnaround situation.

Finally, the RPA score is subject to various biases (Kahneman, 2011) of observers facing the turnaround situations. Research to explore the typical biases and considerations applied by expert versus novice practitioners is overdue.

An unintended application/consequence of the affordance framework was its potential use for new venture start-up decisions for funding by venture capitalists. The framework is useful as it can assess the opportunity proposed although its judgments are much more speculative at the early stages of the venture creation process. This may create an opportunity for research in new venture creation assessment.

\section{References}

Bainbridge, S. 2006. 'Much ado about little-directors' fiduciary duties in the vicinity of insolvency', Journal of Business and Technology Law, 05-26.

Baldiga, N.R. 1996. 'Is this plan feasible? An empirical legal analysis of plan feasibility', Commercial Law Journal, 101: 115132.

Barker, V.L. 2005. 'Traps in diagnosing organisational failure', Journal of Business Strategy, 26(2): 44-50.

Barker, V.L. \& Barr, P.S. 2002. 'Linking top manager attributions to strategic reorientation in declining firms attempting turnarounds', Journal of Business Research, 55: 963-979.

Barker, V.L. \& Mone, M.A. 1998. 'The mechanistic structure shift and strategic reorientation in declining firms attempting turnarounds', Human Relations, 51(10): 1127 -1258.

Barker, V.L. \& Duhaime, I.M. 1997. 'Strategic change in the turnaround process: Theory and empirical evidence', Strategic Management Journal, 18: 13-38.

Barondes, R.D., Fairfax, L., Hamermesh, L.A. \& Lawless, R. 2007. 'Twilight in the zone of insolvency: Fiduciary duty and creditors of troubled companies - history \& background', Journal of Business \& 
Technology Law. 229. [Online] available: http://digitalcommons. law.umaryland.edu/jbtl/vol1/iss $2 /$

Baird, S. \& Lorence, M. 2012. 'Predicting success: A doctoral research study', Journal of Corporate Renewal, Nov/Dec: 20-23.

Baumard, P. \& Starbuck, W.H. 2005. 'Learning from failures: Why it may not happen', Long Range Planning, 38: 281-298.

Boyle, R.D. \& Desai, H.B. 1991. 'Turnaround strategies for small firms', Journal of Small Business Management, 29(3): 33 - 42.

Bradstreet, R. 2010. 'The leak in the Chapter 6 lifeboat: Inadequate regulation of business rescue practitioners may adversely affect lenders: Willingness and the growth of the economy', South African Mercantile Law Journal, 195-213. [Online] available: http://www.companylaw.uct.ac.za

Brayen, D. \& Tilley, A. 2011. 'Best practices guideline: Turnarounds', Corporate Finance Faculty, 53: 4-23.

BR Portal. 2013. Second-generation scenarios for business rescue in South Africa. [Online] available: http://www.brportal.co.za/forum

Calandro, J. 2009. 'Distressed M\&A and corporate strategy: Lessons from Marvel Entertainment Group's bankruptcy', Strategy \& Leadership, 37(4): 23-32.

Cameron, K., Zammuto, R. 1983. 'Matching managerial strategies to conditions of decline', Human Resource Management, Winter 22(4): 359-375.

Cameron, K.S., Whetten, D.A. \& Kim, M.U. 1987. 'Organisational dysfunctions of decline', Academy of Management Journal, 30(1): 126-138.

Cannon, M.D. \& Edmondson, A.C. 2005. 'Failing to learn and learning to fail (intelligently): How great organisations put failure to work to innovate and improve', Long Range Planning, 38: 299-319.

Castrogiovanni, G.J. 1991. 'Environmental munificence: A theoretical assessment', Academy of Management Review 16(3): $542-565$.

Castrogiovanni, G.J., Baliga, B.R. \& Kidwell, R.E. 1992. 'Curing sick businesses: Changing CEOs in turnaround efforts', Academy of Management Executives, 6(3): 26-39.

Chemero, A. 2000. 'What events are', Ecological Psychology 12(1): $37-42$.

Chemero, A., Klein, C. \& Cordeiro, W. 2003. 'Events as changes in the layouts of affordances', Ecological Psychology 15(1): 19-28.

Chemero, A. 2003. 'An outline of a theory of affordances', Ecological Psychology 15(2): 181-195.

Chesbrough, H. 2007. 'Business model innovation: It's not just about technology anymore', Strategy \& Leadership 35(6): 12-17.

Collet, N., Pandit, N.R. \& Saarikkp, Jukka. 2014. 'Success and failure in turnaround attempts. An analysis of SME's within the finish restructuring of enterprises act', Entrepreneurship \& Regional Development, 26: 123-141.

Companies Act and Regulations no 71 of 2008. 2011. Juta. ISBN: 9780702185984.
Conradie, S. \& Lamprecht, C. 2015. 'Business rescue: How can its success be evaluated at company level?', Southern African Business Review, 19(3): 1- 29.

Cook, G.A.S., Pandit, N.R. \& Milman, D. 2011. 'A resource-based analysis of bankruptcy law, SMEs and corporate recovery', International Small Business Journal: 1-19.

Demir, R. 2015. 'Strategic activity as bundled affordances', British Journal of Management. 26: S125-S141.

Eisenhardt, K.M. \& Schoonhoven, C.B. 1996. 'Resource-based view of strategic alliance formation: Strategic and social effects in entrepreneurial firms', Organisation Science, 7(2): 136 -150.

Eow, I. 2006. 'The door to reorganisation: Strategic behaviour or abuse of voluntary administration?', Melbourne University Law Review, 30: 300-338.

Floyd, S.W \& Lane, P.J. 2000. 'Strategizing through organisations: Managing role conflict in strategic renewal', Academy of Management Review, 25(1): 154-177.

Francis, J.D. \& Desai, A.B. 2005. 'Situational and organisational determinants of turnaround', Management Decision, 43(9): 12031224

Fredenberger, W.B. \& Bonnici, J. 1994. 'Turnaround phases: Extending the life cycle theory', American Business Review, January: 59-65.

Garg, V.K., Walters, B.A. \& Priem, R.L. 2003. 'Chief executive scanning emphasis, environmental dynamism, and manufacturing firm performance', Strategic Management Journal, 24(8): 725-744.

Gherardi, S. 1995. 'When will he say: "Today the plates are soft"? The management of ambiguity and situated decision making', Studies in Cultures, Organisations and Societies, 1(1): 9-27.

Guha, M. 2016. 'Organisational slack in declining firms and surviving firms', Journal of Strategy and Management, 9(1): 93114.

Gibson, J.J. 1979. The ecological approach to visual perception. Boston. Houghton Mufflin. Reprinted 1986. Erlbaum.

Gibson, J.G. 1988. 'Exploratory behaviour in the development of perceiving, acting, and the acquiring of knowledge', Annual Review Psychology, 39: 1-42.

Gibson, J.G. 2000. 'Where is the information for affordances?', Ecological Psychology, 12(1): 53-56.

Guha, 2015. 'Leading fast turnarounds', Business Strategy Review, Autumn: 28-33.

Handy, C. 2002. The empty raincoat-New thinking for a new world. Arrow books. ISBN. 9780099301257 . London.

Hambrick, D.C. \& Schecter, S.M. 1983. 'Turnaround strategies for mature industrial- product business units', Academy of Management Journal, 26(2): 231-248.

Ho, J.K.S. 2008. 'Economic theories of the firm versus stakeholder theory: Is there a governance dilemma?', Hong Kong Law Journal, 38(2): 339-424. 
Hofer, C.W. 1980.'Turnaround strategies', The Journal of Business Strategy, 1(1): 19-31.

Janse van Rensburg, A. 2016. Factual evaluation of rescue feasibility: a reasonable prospect approach. MCom dissertation presented at University of Pretoria.

Joubert, T. 2013. "Reasonable possibility" versus "reasonable prospect": Did business rescue success in creating a better test than judicial management?', Tydskrif vir Romeins Hollandse Reg, 76: 550-563.

Kahl, M. 2002. 'Economic distress, financial distress, and dynamic liquidation', Journal of Finance, 57(1): 135-168.

Kahneman, D. 2011. Thinking, fast and slow. London: Penguin.

Kanter, R.M. 2003. 'Leadership and the psychology of turnarounds', Harvard Business Review, June: 59-67.

Klopper, H. \& Bradstreet, R.S. 2014. 'Averting liquidations with business rescue: Does a section 155 compromise place the bar too high?', Stellenbosch Law Review, 3: 549-565.

Lorange, P. \& Nelson, R.T. 1987. 'How to reorganise-and avoidorganisational decline', Sloan Management Review, 28(3): 41-48.

Madrid- Guijarro, A. Garcia- Perez- de- Lema, D. \& Van Auken, H. 2011. 'An analysis of non-financial factors associated with financial distress', Entrepreneurship \& Regional Development, 23: 159-186.

McCann, P. 2009. Turnarounds: Brains, guts and stamina. Bloomington, IND: Trafford Publishing.

Mellahi, K. 2005. 'The dynamics of boards of directors in failing organisations', Long Range Planning, 38: 261-279.

Mindlin, P. 2013. Comparative analysis of Chapter 6 of the South African Companies Act 71 of 2008. Companies Law Symposium. Johannesburg, South Africa, 1 March. [Online] available: http://www.brportal.co.za/resources.

Mirabile, R.J. 1997. 'Everything you wanted to know about competency modelling', Training \& Development, August: 73-77.

Morris, M. Schindehutte, M. \& Allen, J. 2005. 'The entrepreneur's business model: Toward a unified perspective', Journal of Business Research, 58: 726-735.

Nadkarni, S. \& Barr, P.S. 2008. 'Environmental context, managerial cognition, and strategic action: An integrated view', Strategic Management Journal, 29(13): 1395-1427.

Preston, A. 1986. 'Interactions and arrangements in the process of informing', Accounting Organisations and Society, 11(6): 521-540.

Pretorius, M. 2008. 'When Porter's generic strategies are not enough: Complementary strategies for turnaround situations', Journal of Business Strategy, 29(6): 19-28.

Pretorius, M. 2009. 'Defining business decline, failure and turnaround: A content analysis', South African Journal of Entrepreneurship and Small Business Management, 2(10): 1-16.

Pretorius, M. 2013. Tasks and activities of the business rescue practitioner: A strategy as practice approach', South African Business Review, December 17(3): 1-26. [Online] available:
http://www.unisa.ac.za/contents/faculties/service_dept/docs/Sabvie w_17_3_Chap\%201.pdf

Pretorius, M. \& Du Preez, W. 2013. 'Constraints on decision making regarding post-commencement finance in business rescue', South African Journal of Entrepreneurship and Small Business Management, 6: 168-191.

Pretorius, M. \& Holtzhauzen, G.T.D. 2008. 'Critical variables of venture turnarounds: A liabilities approach', Southern African Business Review, 12(2): 87-107.

Pretorius, M. \& Holtzhauzen, G.T.D. 2013. 'Business rescue decision making through verifier determinants: Ask the specialists', South African Journal of Management Sciences, 16(4): 468-485. [Online] available: http://sajems.org/index.php/sajems/issue/ view/37.

Pretorius, M. \& Rosslyn-Smith, W. 2014. 'International guidelines for business rescue plans', South African Business Review, 18(2): 108-139.

Pretorius, M. 2014. 'A competency framework for the business rescue practitioner profession', Acta Commerci', 14(2): 1-15.

Pretorius, M. 2015. Business rescue status report -. Unpublished report presented to the Regulator. December.

Rezazade Mehrizi, M.H. \& Lashkarbolouki, M. 2016. 'Unlearning troubled business models: From realisation to marginalisation', Long Range Planning, 49(3): 298-323.

Robbins, K.D. \& Pearce, J.A. 1992. 'Turnaround: Retrenchment and recovery’, Strategic Management Journal, 13(4): 287-309.

Sanders, J.T. 1997. 'An ontology of affordances', Ecological Psychology, 9(1): 97-112.

Sheppard, J.P. \& Chowdhury, S.D. 2005. 'Riding the wrong wave: Organisational failure as a failed turnaround', Long Range Planning, 38: $239-260$.

Sheppard, J.P. \& Shamsud, D.C. 2005. 'Riding the wrong wave: Organisational failure as a failed turnaround', Long Range Planning, 38: $239-260$.

Smith, M. \& Graves, C. 2005. 'Corporate turnaround and financial distress', Managerial Auditing Journal, 20(3): 304-320.

Schmitt, A. \& Raisch, S. 2013. 'Corporate turnarounds: The duality of retrenchment and recovery', Journal of Management Studies, 50(7): 1216-1244.

Schmitt, A, Barker III, V.L. Raisch, S. \& Whetten, D. 2015. 'Strategic renewal in times of environmental scarcity', Long Range Planning. 20(3): 304-320. doi; 10.1016/j.lrp.2015.08.004.

Stoffregen, T.A. 2000. 'Affordances and events', Ecological Phycology. 12(1): 1-28.

Stovall, C. \& Brodsky 2013. 'Unearthing fraud, waste, misuse. Data analysis may boost recoveries, plug cash leaks', Journal of Corporate Renewal, October: 10-14.

Sudarsanam, S. \& Lai, J. 2001. 'Corporate financial distress and turnaround strategies: An empirical analysis', British Journal of Management, 12: 183-199. 
Thornhill, S. \& Amit, R. 2003. 'Learning about failure: Bankruptcy, firm age, and the resource-based view', Organisation Science, 14(5): $497-509$.

Timmons, J.A. 1999. New Venture Creation-Entrepreneurship for the $21^{\text {st }}$ century. MacGraw-Hill International Editions.

Trahms, C.A., Ndofor, H.A. \& Sirmon, D.G. 2013. 'Organisational decline and turnaround: A review and agenda for future research', Journal of Management, 39: 1227-1307.

Tung, F. 2006. 'Gap filling in the zone of insolvency', Journal of Business and Technology Law, 1(2): 607-631

Walshe, K., Harvey, G., Hyde, P. \& Pandit, N. 2004. 'Organisational failure and turnaround: Lessons learned for public services from the for-profit sector', Public money \& Management, 24(4): 201-208.

Weitzel, W. \& Jonsson, E. 1991. 'Reversing the downward spiral: Lessons from W.T. Grant and Sears Roebuck', Academy of Management Executive, 5(3): 7-22. 